\title{
Molecular Typing with BOX-PCR of Staphylococcus aureus Isolated from Milk Samples
}

\author{
Elif GÜLBAHÇE MUTLU ${ }^{1 *}$, Emine ARSLAN ${ }^{2}$ \\ ${ }^{1}$ KTO Karatay University, Faculty of Medicine, Department of Medical Biology, Konya, Turkey \\ ${ }^{2}$ Selçuk University, Faculty of Science, Department of Biology, Konya, Turkey \\ (ORCID: 0000-0003-2391-2152) (ORCID: 0000-0002-0782-506X)
}

\begin{abstract}
The aim of this study is to characterize 98 Staphylococcus aureus isolated from bovine subclinical mastitis in Konya region with BOX primer. A total of 28 band profiles ranging from 950-300 bp were generated by the BOX primer. This band profile was evaluated according to Nei homology and a dendogram (UPGMA) was obtained. According to the data obtained, 95 isolates with genetic similarity varying between 50-100\% were in the same group. This study demonstrates that the BOX-PCR technique provides a fast and reliable tool to investigate epidemiology in S. aureus.
\end{abstract}

Keywords: Molecular typing, bovine mastitis, repetitive DNA sequences, Staphylococcus aureus.

\section{Süt Örneklerinden İzole Edilen Staphylococcus aureus'un BOX-PCR ile Moleküler Tiplendirilmesi}

\begin{abstract}
$\ddot{\mathbf{O} z}$
$\mathrm{Bu}$ çalışmanın amacı Konya bölgesindeki sığır subklinik mastitinden izole edilen 98 Staphylococcus aureus'u BOX primeri ile karakterize etmektir. BOX primeri tarafindan 950-300 bç arasında değişen toplam 28 bant profili oluştu. Bu bant profili Nei homolojisine göre değerlendirildi ve bir dendogram (UPGMA) elde edildi. Elde edilen verilere göre \% 50-100 arasında değişen oranlarda genetik benzerlik gösteren 95 izolat aynı grupta yer aldı. $\mathrm{Bu}$ çalışma, BOX-PCR tekniğinin S. aureus'ta epidemiyolojiyi araştırmak için hızlı ve güvenilir bir araç sağladığını göstermektedir.
\end{abstract}

Anahtar kelimeler: Moleküler tiplendirme, sığır mastitis, tekrar eden DNA dizileri, Staphylococcus aureus.

\section{Introduction}

Bovine mastitis caused by Staphylococcus aureus is an infectious disease that causing significant economic losses in the dairy industry [1,2]. Therefore, S. aureus plays an important role in the fight against mastitis. Mastitis is treated and prevented by the use of antibiotics to cure diseases in dairy cattle herds [3-6]. However, the random use of antibiotics threatens public health due to drug multiresistance and risk of residual sprains in milk [7]. Furthermore, the source of this infection must be correctly identified for good treatment and protection against this infection [6]. DNA-based molecular typing methods have become more important because they are more efficient and have high sensitivity in uncovering the source of infection that concerns public health [8]. BOX-PCR methods have been found to be reliable in the identification of Staphylococcus strains [2, 9-11]. In these methods, which are based on the replication of repeating sequences placed at intergenic positions in the genome with specific primers, DNA fingerprints are extracted using 154 bp length BOX element $[12,13]$. These genomic fingerprints from bacterial isolates distinguish species, subspecies and strain levels and are also

"Corresponding author: elifgulbahcemutlu@gmail.com

Received: 02.11.2020, Accepted: 18.02.2021 
successfully applied in medical, agricultural, industrial and environmental studies to determine microbial diversity $[2,6,13]$.

In the study, advanced typing was aimed in 98 S. aureus isolates isolated from mastitis cows in Konya region by BOX-PCR methods.

\section{Materials and Methods}

\subsection{Bacterial strains}

98 S. aureus strains were isolated from milk samples with mastitis in Konya Region. These strains were recognized as $S$. aureus by a standard procedure [14]. After, these strains confirmed with the VITEK 2 system (bioMerieux).

\subsection{Bacteria Cultivation and DNA Extraction}

All strains were planted in brain heart infusion (BHI) broth and cultivation for $18 \mathrm{~h}$ at $37{ }^{\circ} \mathrm{C}$. Later, bacterial DNA was isolated as described Ausubel et al. [15] with some modifications.

\subsection{PCR methods for Genotyping}

Isolated DNA was amplified using the repetitive element sequence. The nucleotide sequence of primer used in this study is as follow; BOXA1R 5'- TACGGCAAGGCGACCCTGACG-3' [16].

Each $25 \mu \mathrm{L}$ of PCR mix contained $2.5 \mathrm{mM}$ dNTP mix, 10X PCR reaction buffer $(50 \mathrm{mM} \mathrm{KCl}$, $10 \mathrm{mM}$ Tris- $\mathrm{HCl}, \mathrm{pH}=9, \% 0.1$ TritonX-100), $3 \mathrm{mM} \mathrm{MgCl}$, 75 pmol of primer, $2.5 \mathrm{U}$ of Taq polymerase (Fermentas), and 50ng of template DNA. PCR reactions was performed in a Mastercycler Gradient thermal cycler (Eppendorf, Hamburg, Almanya). Amplifications of mixtures were carried out following cycling conditions: an initial denaturation at $95{ }^{\circ} \mathrm{C}$ for $7 \mathrm{~min}$ was followed by 30 cycles of denaturation at $94{ }^{\circ} \mathrm{C}$ for $1 \mathrm{~min}$, annealing at $53^{\circ} \mathrm{C}$ for $1 \mathrm{~min}$, an extension at $72^{\circ} \mathrm{C}$ for $1 \mathrm{~min}$, and ending with a final extension at $65^{\circ} \mathrm{C}$ for $16 \mathrm{~min}$.

Amplified products were separated by electrophoresis in $2 \%$ agarose gel, stained with ethidium bromide $(0.5 \mu \mathrm{g} / \mathrm{mL})$, and visualized by UV-transilluminator. Gel image was recorded with DNA imaging system (Vilber Lourmat, Lamirault, Fransa).

\subsection{Data Analysis}

The genotypes of $S$. aureus isolates were assessed using Bio1D++ computer program. Band profiles were recored visibly as (1) or (0). Genetic similarity between strains was evaluated according to Nei homology. And then Cluster analysis was carried out with the UPGMA.

\section{Results and Discussion}

With BOXA1R primer, $98 \mathrm{~S}$. aureus isolate totally generated 28 DNA fragments in lengths between 950-300 bp. Although monomorphic bands are not observed in all isolates, the common bands in most isolates are the band patterns in sizes $900 \mathrm{bp}, 800 \mathrm{bp}, 500 \mathrm{bp}, 475 \mathrm{bp}, 410 \mathrm{bp}, 350 \mathrm{bp}$ and 300 bp Although monomorphic bands are not observed in all isolates, the common bands in most isolates are the band patterns in sizes 900 bp, 800 bp, 500 bp, 475 bp, 410 bp, $350 \mathrm{bp}$ and 300 bp (Figure 1).

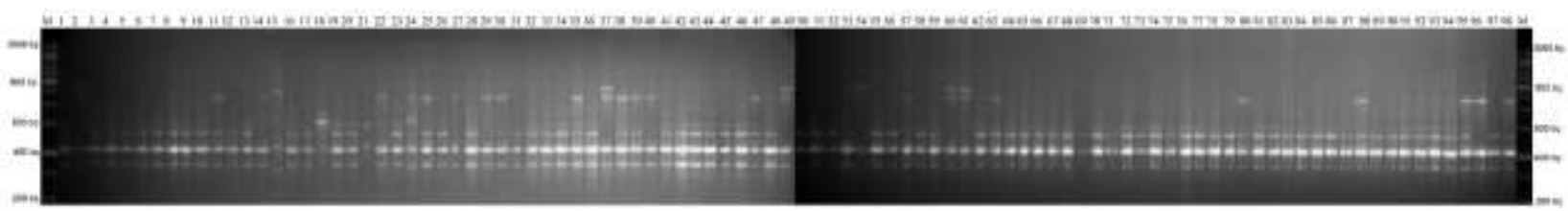

Figure 1. Agarose gel electrophoresis of BOX-PCR products (Line M; marker) 
A dendrogram was obtained evaluating the presence or absence of total of 28 bands between 950-300 bp in Figure 4. According to the dendrogram, while 95 isolates showing genetic similarity by rates ranging between $50-100 \%$ are located in the first group, three isolates $(15,18,21)$ forming the second group were separated by $77 \%$ from the first group. In addition, the presence of many isolates which were $100 \%$ similar in the first group was noteworthy.

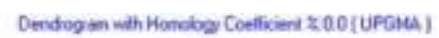

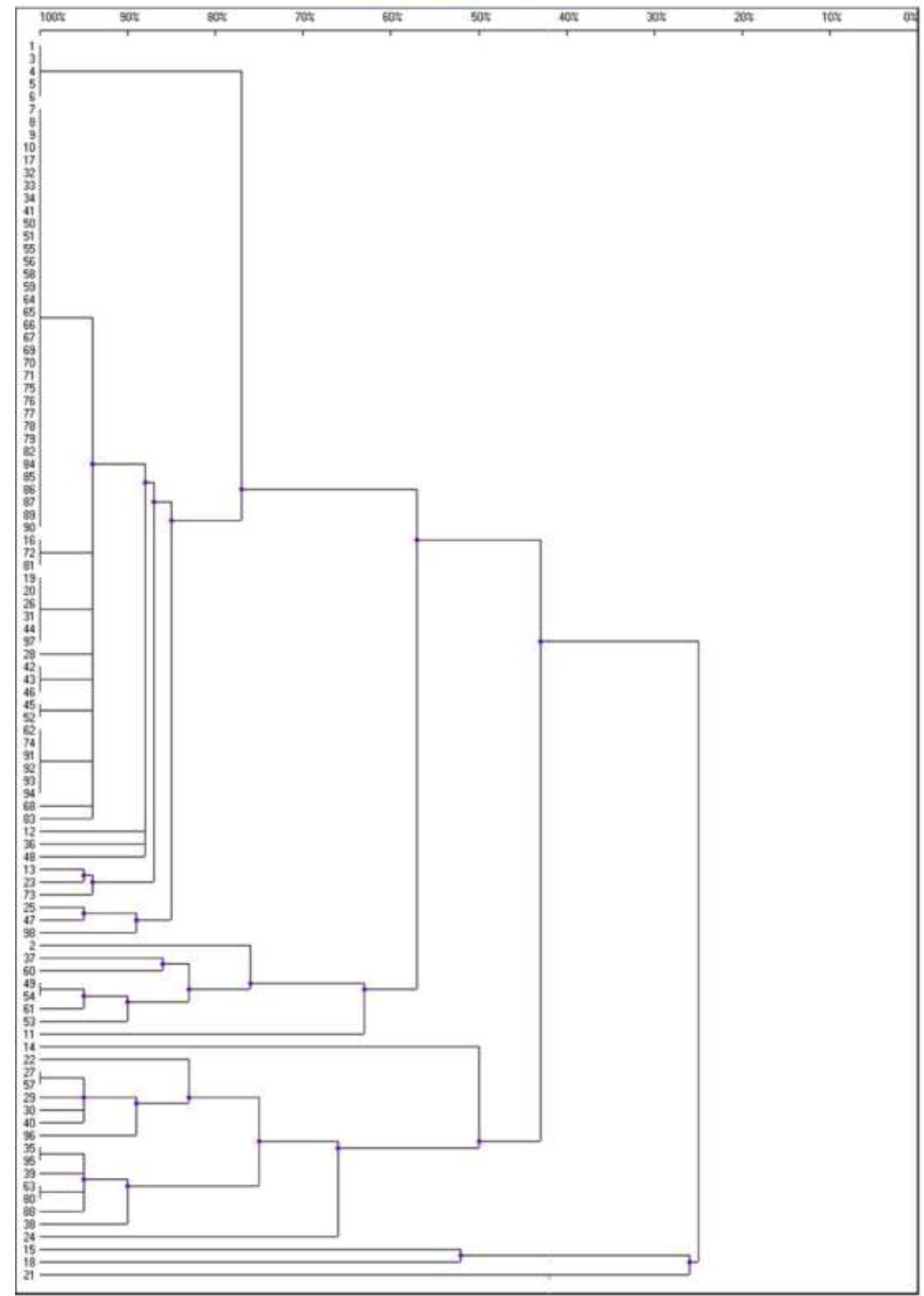

Figure 2. Dendrogram of genetic relationships of S. aureus strains by BOX-PCR 
In recent years, molecular genotyping methods have become the gold standard for the definition of mastitis because they provide specific, rapid, qualitative, quantitative, economic and large-scale diagnosis [17]. Some of these may be exemplified by methods such as Restriction Fragment Length Polymorphism (RFLP) [18], PFGE [19, 20], AFLP [20], plasmid profiles [21-23], RAPD-PCR [24], REP-PCR [25] and ERIC-PCR [26].

REP-PCR typing was determined to be better at distinguishing compared to PCR methods based on repetitive elements such as amplifications of Tn916-16S rRNA gene spacer region [27] and inter 16S-23S rRNA gene spacer region [28]. It was showed that REP-PCR is a rapid screening procedure in classification of a large number of bacteria isolates and provides high distinction [29]. The repeatability of REP-PCR, which is extremely important when used for epidemiological purposes is discovered to be excellent contrary to repeatability of PCR (AP-PCR; Arbitrary Primers-Polymerase Chain Reaction) done using randomly selected PCR primers [30]. In addition, when compared with PFGE it was advocated that REP-PCR is as good as PFGE besides having easy and fast performance as an important advantage [8, 31].

REP- and ERIC- primers have been strongly used in identification of gram (-) $[12,32,33]$ and gram $(+)[26,34-36]$ bacteria strains.

This study is the first study aimed to determine the genetic relationship between $S$. aureus obtained from the milk with mastitis by BOX primers. Although amplification of $S$. aureus strains by REP-PCR could not be performed by REP1R-I and REP2-I primers by some researchers [11], Wood et al [37], successful amplification of gram (+) bacteria such as $S$. aureus could be performed by primers REP1R-I and REP2-I. However very good products have been obtained which allow the identification of $S$. aureus strains as a result of amplification with another REP primer (RW3A) [2, 9, 30, 38, 39, 40]. In contrast to this study, BOX elements were screened in $10 \mathrm{~S}$. aureus isolates, but no amplification was obtained [10]. Another study report confirms that BOXA1 primer was not hybridized in S. aureus genome.

Most isolates exhibit $100 \%$ similarity profiles, but few of them were determined to show similarity under $60 \%$ in all two methods in this study. While Alam et al [41] reported that only 2 Streptococci strains showed similarity more than 90\%, most strains showed less than $90 \%$ (down to 40\%) similarity; Staphylococcus epidermidis strains were extremely similar according to the findings REP, ERIC and BOX [11].

Wieser and Busse [11] obtained fragments of S. epidermidis strains > 1100-350 bp in BOXPCR. BOX-PCR was not encountered in S. aureus strains and BOX-PCR (BOXA1) was applied to the Streptococcus pnemoniae [10] and Burkholderia pseudomallei strains [42] obtaining fragments between $300-1500 \mathrm{bp}$. In contrast to the previous study, up to $950 \mathrm{bp}$ fragments were obtained in this study. The dendrogram obtained as a result of the combination was indicated by its similarity to the dendrogram as a result of the BOX-PCR. BOX-PCR (36 different profiles) showed that many strains had the same band profiles showing highly similar band patterns. We can explain so much similarity by the probability that the pathogen could be contaminated during milking in the herd and so the origin of most of the isolates are the same. Wieser and Busse [11] advocated that complementary sequences of REP primers are only in some Staphylococcus species and so the combination of REP- and BOX-PCR are not sufficient in the distinction of Staphylococcus species, but these methods provide an identification among S. epidermidis strains by forming specific bands to the strain.

\section{Conclusion}

It is possible to generate a fingerprint database with these fast and good molecular methods such as BOX PCR. Thus, it can be useful in finding the source of the disease outbreak, routine identification of the microorganism, and vaccine production studies. Thus, the duration of treatment against mastitis may be shortened by rapid prognosticate.

\section{Acknowledgments}

This research was supported by TUBITAK (108T290). Thanks to Prof. Dr. Uçkun Sait UÇAN for assistance in collecting milk and identifying bacteria. In addition, this study was presented as an oral presentation at the 24th National Biochemistry Congress and published as abstract in the congress book. 


\section{Authors' Contributions}

E.G.M. and E.A. conceived the original idea and build. E.A. supervised the project. The experiments were performed by E.G.M. and E.A. All authors contributed to the writing of the manuscript. Some of the bacteria samples that Dr. Emine ARSLAN isolated in her doctoral thesis were used in this study.

\section{Statement of Conflicts of Interest}

There is no conflict of interest between the authors.

\section{Statement of Research and Publication Ethics}

The author declares that this study complies with Research and Publication Ethics

\section{References}

[1] Han H.R., Pak S.II., Kang S.W., Jong W.S., Youn C.J. 2000. Capsular polysaccharide typing of domestic mastitis causing Staphylococcus aureus strains and its potential exploration of bovine mastitis vaccine development, I. Capsular polysaccharide typing, isolation and purification of the strains. Journal of Veterinary Science, 1: 53-60.

[2] Reinoso E., Bettera S., Odierno L., Bogni C. 2007. Rep-PCR of Staphylococcus aureus strains isolated from bovine mastitis in Argentina. Brazilian Journal of Veterinary Research and Animal Science, 44: 115-121.

[3] Pellegrino M.S., Frola I.D., Odierno L.M., Bogni C.I. 2011. Mastitis bovina: resistencia a antibióticos de cepas de Staphylococcus aureus asiladas de leche. Revista electrónica de Veterinaria., 12: 1-14.

[4] Silva E.R., Pereira A.M.G., Moraes W.S., Santoro K.R., Silva T.R.M. 2012. Perfil de sensibilidade antimicrobiana in vitro de Staphylococcus aureus isolado de mastite subclínica bovina. Revista Brasileira de Saúde e Produção Animal, 13: 701-711.

[5] Teixeira J.P., Silva N., Fonseca L.M., Costa G.M. 2014. Uso de PCR Duplex para detecção dos genes femA e mecA e determinação da concentração inibitória mínima (CIM) em Staphylococcus aureus isolados de leite cru. Revista do Instituto Adolfo Lutz, 73: 272-279.

[6] Xavier A.R.E.O., Almeida A.C, Souza C.N, Silva L.M.V., Ruas A.X.A., Sanglard D.A., Júnior A.F.M, Oliveira A.M.E., Xavier M.A.S. 2017. Phenotypic and genotypic characterization of Staphylococcus aureus isolates in milk from flocks diagnosed with subclinical mastitis. Genetics and molecular research, 29: 16 (2).

[7] Ganda E.K., Bisinotto R.S., Decter D.H., Bicalho R.C. 2016. Evaluation of an on-farm culture system (accumast) for fast identification of milk pathogens associated with clinical mastitis in dairy cows. PLoS One, 13, 11 (5): e0155314.

[8] Tenover F.C., Arbeit R., Archer G., Biddle,J., Byrne S., Goering R., Hancock G., Herbert G.A., Hill B., Hollis R., Jarvis W.R., Kreiswirth B., Eisner W., Maslow J., Mcdougal L.K., Miller J.M., Mulligan M., Pfaller M.A. 1994. Comparison of traditional and molecular methods of typing isolates of Staphylococcus aureus. Journal of Clinical Microbiology, 32: 407-415.

[9] Del Vecchio V.G., Petroziello J.M., Gress M.J., Mcclesky F.K., Melcher G.P., Crouch H.K., Lupski J.R. 1995. Molecular genotyping of methicillin-resistant Staphylococcus aureus via fluorophore enhanced repetitive sequence VCR. Journal of Clinical Microbiology, 33: 2141-2144.

[10] van Belkum A., Sluijuter M., de Groot R., Verbrugh H., Hermans P.W. 1996. Novel BOX repeats PCR assay for high-resolution typing of Streptococcus pneumoniae strains. Journal of Clinical Microbiology, 34: 1176-1179.

[11] Wieser M., Busse H.J. 2000. Rapid identification of Staphylococcus epidermidis. International Journal of Systematic and Evolutionary Microbiology, 50: 1087-1093.

[12] Versalovic J., Koeuth T., Lupski J.R. 1991. Distribution of repetitive DNA sequences in eubacteria and application to fingerprinting of bacterial genomes. Nucleic Acids Research, 19: $6823-6831$. 
[13] Versalovic J., Schneider M., de Bruijn F.J., Lupski J.R. 1994. Genomic fingerprinting of bacteria using repetitive sequence-based PCR (rep-PCR). Methods in Molecular Biology, 5: 25-40.

[14] Holt J.G., Krieg N.R., Sneath P.H.A., Staley J.T. Willams S.T. 1994. Bergey's manual of Determinative Bacteriology (Ninth edition), Baltimore: Williams \& Wilkins.

[15] Ausubel F.M., Kingston R.E., Brent R., Moore D.D. Seidman J.G., Smith J.A., Struhl K. 1991. Current protocols in molecular biology. New York: Greene Publishing Associates \& Wiley Interscience.

[16] Louws F.J., Fulbright D.W., Stephens C.T., De Bruijn F.J. 1994. Specific genomic fingerprints of phytopathogenic Xantho-monas and Pseudomonas pathovars and strains, generated with repetitive sequences and PCR. Applied and Environmental Microbiology, 60: 2286-2295.

[17] El-Sayed A., Awad W., Abdou N.E., Castañeda Vázquez H. 2017. Molecular biological tools applied for identification of mastitis causing pathogens. International Journal of Veterinary Science, 5 (2): 89-97.

[18] Owen R.J. 1989. Chromosomal DNA fingerprinting-a new method of species and strain identification applicable to microbial pathogens. Journal of Medical Microbiology, 30: 89-99.

[19] Murray B.E., Singh K.V., Heath J.D., Sharma B.R., Weinstock G.M. 1990. Comparison of genomic DNAs of different enterococcal isolates using restriction endonucleases with infrequent recognition sites. Journal of Clinical Microbiology, 28: 2059-2063.

[20] Szaluś-Jordanow O., Chrobak D., Pyrgiel M., Lutyńska A., Kaba J., Czopowicz M., Witkowski L., Kizerwetter-Świda M., Binek M., Frymus T. 2013. PFGE and AFLP genotyping of Staphylococcus aureus subsp. anaerobius isolated from goats with Morel's disease. Archives of Microbiology, 195 (1): 37-41.

[21] Litwin C.M., Storm A.L., Chipowsky S., Ryan K.J. 1991. Molecular epidemiology of Shigella infections: plasmid profiles, serotype correlation, and restriction endonuclease analysis. Journal of Clinical Microbiology, 29: 104-108.

[22] Uçan U.S., Açık L., Çelebi A., Erganiş O., Arslan E. 2005. Plasmids and Protein Patterns of Ecsherichia coli Isolated from Bovine Mastitis in Konya, Turkey. Turkish Journal of Veterinary and Animal Sciences, 29: 475-480.

[23] Arslan E., Çelebi A., Açık L., Uçan U.S. 2009. Characterization of Coagulase Positive Staphylococcus Species Isolated from Bovine Mastitis by Protein and Plasmid Patterns. Turkish Journal of Veterinary and Animal Sciences, 33 (6): 493-500.

[24] Arslan E., Leyla A., Uçan U.S. 2005. Determination by RAPD-PCR of Relationship Degrees of $S$. aureus and $S$. intermedius Strains Isolated from Bovine Mastitis. S. Ü. Veteriner Bilimleri Dergisi, 21 (1-2): 65-69.

[25] Arslan E., Ertuğrul K., Albayrak A. 2009. Staphylococcus aureus ve Staphylococcus intermedius Suşlarının REP-PZR Metodu ile Tiplendirilmesi. Selçuk Universitesi Fen Fakültesi Fen Dergisi, 2 (34): 85-92.

[26] Arslan E., Gülbahçe Mutlu E. 2016. Genotyping of Staphylococcus aureus Strains Isolated from Bovine Mastitis in Turkey by using ERIC-PCR Method. Pakistan Journal of Zoology, 48 (6): 1747-1752.

[27] Cuny C., Witte W. 1996. Typing of Staphylococcus aureus by PCR for DNA sequences flanked by transposon Tn916 target region and ribosomal binding site. Journal of Clinical Microbiology, 34: 1502-1505.

[28] Gürtler V., Barrie H.D. 1995. Typing of Staphylococcus aureus strains by PCR-amplification of variable-length 16S-23S rDNA spacer regions: characterization of spacer sequences. Microbiology, 141: 1255-1265.

[29] Deplano A., Schuermans A., Van Eldere J., Witte W., Meugnier H., Etienne J., Grundmann H., Jonas D., Noordhoek G.T., Dijkstra J., van Belkum A., van Leeuwen W., Tassios P.T., Legakis N.J., van der Zee A., Bergmans A., Blanc D.S. Tenover F.C., Cookson B.C., O'Neil G., Struelens M.J. 2000. Multicenter evaluation of epidemiological typing of methicillin resistant Staphylococcus aureus strains by repetitive element PCR analysis. The European Study Group on Epidemiological Markers of the ESCMID. Journal of Clinical Microbiology, 38: 3527-3533.

[30] van Belkum A., Kluytamans J., van Leeuwen W., Bax R., Quint W., Peters E., Fluit A., Vandenbroucke-Grauls C., van den Brule A., Koelman H. 1995. Multicenter evaluation of 
arbitrarily primed PCR for typing of Staplycoccus aureus strains. Journal of Clinical Microbiology, 33: 1537-1547.

[31] Ross T.L., Merz W.G., Farkosh M., Carroll C. 2005. Comparison of an automated repetitive sequence-based PCR microbial typing system to pulsed-field gel electrophoresis for analysis of outbreaks of methicillin-resistant Staphylococcus aureus. Journal of Clinical Microbiology, 43: 5642-5647.

[32] Kerouanton A., Brisabois A., Grout J., Picard B. 1996. Molecular epidemiological tools for Salmonella dublin typing FEMS Immunology and Medical Microbiology, 14: 25-29.

[33] Appuhamy S., Parton R., Coote J.G., Gibbs H.A. 1997. Genomic fingerprinting of Haemophilus somnus by a combination of PCR methods. Journal of Clinical Microbiology, 35: 288-291.

[34] Rajashekara G., Koeuth T. Nevile S., Back A., Nagaraja K.V., Lupski J.R., Kapur V. 1998. SERE, a widely dispersed bacterial repetitive DNA element. Journal of Medical Microbiology, 47: 489498.

[35] Lessing M.P., Jordens J.Z., Bowler I.C. 1995. Molecular epidemiology of a multiple strain outbreak of methicillin-resistant Staphylococcus aureus amongst patients and staff. Journal of Hospital Infection, 31: 253-260.

[36] van Belkum A., Bax R., Peerbooms P., Goessens W.H.F., Van Leeuwen N., Quint W.G.V. 1992. Comparision of phage typing and DNA fingerprinting by polymerase chain reaction for discrimination of methicillin-resistant Staphylococcus aureus strains. Journal of Clinical Microbiology, 31: 798-803.

[37] Woods C.R., Versalovic J., Koeuth T., Lupski J.R. 1993. Whole-cell repetitive element sequencebased polymerase chain reaction allows rapid assessment of clonal relationship of bacterial isolates. Journal of Clinical Microbiology, 31: 1927-1931.

[38] van der Zee A., Verbakel H., van Zon J.C., Frenay I., van Belkum A., Peeters M., Butting A., Bergmans A. 1999. Molecular genotyping of Staphylococcus aureus strains: comparison of repetitive element sequence-based PCR with various typing methods and isolation of a novel epidemicity marker. Journal of Clinical Microbiology, 37: 342-349.

[39] Shutt C.K., Pounder J., Page S.R., Schaecher B.J., 2005. Clinical evaluation of the DiversiLab microbial typing system using repetitive-sequence-based PCR for Characterization of Staphylococcus aureus strains. Journal of Clinical Microbiology, 43: 1187-1192.

[40] Reinoso E.B., El-Sayed A., Lammler C., Bogni C. Zschock M. 2006. Genotyping of Staphylococcus aureus isolated from humans, bovine subclinical mastitis and food samples in Argentina. Microbiological Research, 163: 314-322.

[41] Alam S., Brailsford S.R., Whiley R.A., Beighton D. 1999. PCR-Based methods for genotyping viridans group streptococci. Journal of Clinical Microbiology, 37: 2772-2776.

[42] Currie B.J., Gal D., Mayo M., Ward L., Godoy D., Spratt B.G., Lipuma J.J. 2007. Using BOXPCR to exclude a clonal outbreak of melioidosis. BMC Infectious Diseases, 7: 68. 